\title{
Mx mRNA expression and RFLP analysis of rainbow trout Oncorhynchus mykiss genetic crosses selected for susceptibility or resistance to IHNV
}

\author{
G. D. Trobridge, S. E. LaPatra, C. H. Kim, J. C. Leong* \\ Center for Salmon Disease Research, Department of Microbiology, Oregon State University, Corvallis, Oregon 97331-3804, USA
}

\begin{abstract}
Three interferon-inducible Mx genes have been identified in rainbow trout Oncorhynchus mykiss and their roles in virus resistance have yet to be determined. In mice, expression of the Mx1 protein is associated with resistance to influenza virus. We report a study to determine whether there was a correlation between the expression of $\mathrm{Mx}$ in rainbow trout and resistance to a fish rhabdovirus, infectious hematopoietic necrosis virus (IHNV). A comparison of Mx mRNA expression was made between different families of cultured rainbow trout selected for resistance or for susceptibility to IHNV. A trout-specific Mx cDNA gene probe was used to determine whether there was a correlation between Mx mRNA expression and resistance to the lethal effects of IHNV infection. Approximately $99 \%$ of trout injected with a highly virulent strain of the fish thabdovirus, IHNV, were able to express full length Mx mRNA at $48 \mathrm{~h}$ post infection. This is markedly different from the expression of truncated, non-functional Mx mRNA found in most laboratory strains of mice, and the ability of only $25 \%$ of wild mice to express functional $\mathrm{Mx}$ protein. A restriction fragment length polymorphism (RFLP) assay was developed to compare the Mx locus between individual fish and between rainbow trout genetic crosses bred for IHNV resistance or susceptibility. The assay was able to discriminate 7 distinct RFLP patterns in the rainbow trout crosses. One cross was identified that showed a correlation between homozygosity at the Mx locus and greater susceptibility to IHN-caused mortality.
\end{abstract}

KEY WORDS: Mx protein - Oncorhynchus mykiss - Interferon response $\cdot$ RFLP

\section{INTRODUCTION}

In vertebrates, the first line of defense against viral infection is the production of interferon (IFN) in virusinfected cells. The IFNs then induce the production of antiviral proteins or IFN-regulated proteins (IRPs) that actually produce virus resistance in the neighboring uninfected cells (for review see Samuel 1991). The Mx family of IRPs are 70 to $80 \mathrm{kD}$ in size and are expressed in either the nucleus or cytoplasm of cells treated with Type I IFNs, IFN $\alpha$ or IFN $\beta$. Some members of this family have been shown to confer resistance to the replication of specific viruses in mice and human cells. For example, the replication of influenza viruses (Staeheli et al. 1986, Frese et al. 1995, Thimme et al. 1995), the

•Corresponding author. E-mail: leongj@bcc.orst.edu rhabdovirus vesicular stomatitis virus (VSV) (Meier et al. 1990, Staeheli \& Pavlovic 1991, Zurcher et al. 1992), the measles paramyxovirus (Schneider-Schaulies et al. 1994), and members of the bunyaviridae (Frese et al. 1996) are inhibited by specific Mx proteins. The mechanism for this inhibition is not completely understood; however, it is thought that $\mathrm{Mx}$ proteins may interact with viral polymerases (Schwemmle et al. 1995, Frese et al. 1996).

Studies of the murine Mx proteins have shown that $\mathrm{Mx}+$ and $\mathrm{Mx}$ - strains of mice are found in both laboratory and wild mice populations. The $\mathrm{Mx}+$ phenotype is inherited as a single dominant autosomal trait (Lindenmann 1964). Upon Type I IFN ind uction, $\mathrm{Mx}+$ mice produce a $72 \mathrm{kD}$ protein whose expression confers resistance to influenza virus at doses that kill $\mathrm{Mx}$ - mice (Horisberger 1983, Staeheli et al. 1986). The Mx- phe- 
notype in some strains is due to a deletion that results in a Mx mRNA with 424 nucleotides (nt) missing from its 3' end and the production of a truncated Mx protein. Curiously, most inbred laboratory mouse strains are $\mathrm{Mx}$ - (Staeheli et al. 1988), and the Mx-allele occurs at about $50 \%$ in wild populations of mice (Haller et al. 1987). The selective advantage of $\mathrm{Mx}$ - alleles is unclear. However, the clear relationship between resistance to virus infection and the $\mathrm{Mx}+$ genotype prompted us to examine rainbow trout for the same correlation.

There have been several reports characterizing IFNlike activity in fish cells in vitro (Gravell \& Malsberger 1965, Beasley \& Siegel 1967, Oie \& Loh 1971, de Sena \& Rio 1975, MacDonald \& Kennedy 1979, Sano \& Nagakura 1982, Tengelsen et al. 1989). Further, the in vivo effectiveness of the trout IFN response to the fish rhabdoviruses viral hemorrhagic septicemia virus (VHSV) (de Kinkelin \& Dorson 1973) and infectious hematopoietic necrosis virus (IHNV) (Eaton 1990) has been documented. The importance of the IFN response in virus resistance in salmonid fish led us to examine the role of the IFN-regulated $\mathrm{Mx}$ proteins in rainbow trout Oncorhynchus mykiss.

We have previously reported the isolation and sequence analysis of $\mathrm{Mx}$ cDNA clones encoding 3 distinct $M x$ proteins of rainbow trout (Trobridge \& Leong 1995, Trobridge et al. 1997a). On further analysis, the expression of these trout $\mathrm{Mx}$ mRNAs and proteins in vivo and in trout tissue culture cells was found to be controlled by such IFN inducers as virus infection and the polyribonucleotide, poly I:C (Trobridge \& Leong 1995, Trobridge et al. 1997 a,b). These clones also provided useful probes to determine whether alterations in the Mx genes similar to those found in mice are also present in salmonid fish. Previous reports had shown that resistance to IHNV is a heritable trait in sockeye and chinook salmon Oncorhynchus nerka (McIntyre \& Amend 1978). A report by Winter et al. (1980) demonstrated a correlation between a specific transferrin genotype and susceptibility to bacterial kidney disease. The question was whether resistance/susceptibility to IHNV was correlated with a specific $\mathrm{Mx}$ mRNA species or restriction fragment length polymorphisms (RFLP) pattern. In the study presented here, the genomes of distinct rainbow trout families selected for different levels of resistance to IHNV were analyzed for Mx RFLP patterns. Fish from each family were also infected with IHNV and after $48 \mathrm{~h}$, the $\mathrm{Mx}$ mRNA species were identified in northern blots.

\section{METHODS}

IHNV susceptibility crosses. Both male and female gametes were collected in individual plastic bags, oxy- genated and kept refrigerated at $4^{\circ} \mathrm{C}$ until fertilization. Single pair matings of Clear Springs strain rainbow trout (Buhl, Idaho, USA) were used in order to maximize the diversity among the selected families within each line. After the eggs were fertilized, they were hardened in water containing a final concentration of $100 \mathrm{~g} \mathrm{ml}^{-1}$ iodophore (Western Chemical Inc., Ferndale, WA) for 15 min and placed in small (2 l) upwelling incubators supplied with ultraviolet disinfected $15^{\circ} \mathrm{C}$ spring water. Surviving fry were fed a standard ration and evaluated for susceptibility to IHNV at $66 \mathrm{~d}$ post hatching.

Cell lines. Two fish cell lines were used for the isolation, propagation, and identification of IHNV used in this study: (1) the CHSE-214 cell line (ATCC CRL 1681) from chinook salmon embryos (Lannan et al. 1984) and (2) epithelioma papulosum cyprini (EPC) cells from common carp (Fijan et al. 1983). Both cell lines were propagated and maintained in minimal essential media (GIBCO Laboratories, Grand Island, NY) supplemented with 2 to $10 \%$ fetal bovine serum (Sigma Chemical Co., St. Louis, MO) and buffered with $1 \mathrm{M}$ HEPES and $7.5 \%$ sodium bicarbonate to $\mathrm{pH} 7.5$. For routine cell propagation, the CHSE-214 cell line was incubated at $20^{\circ} \mathrm{C}$ and the EPC cell line at $25^{\circ} \mathrm{C}$.

Viruses. Virus used in this study was a 1990 isolate of IHNV (220-90) (LaPatra et al. 1991) obtained from rainbow trout at a commercial hatchery in the Hagerman Valley (Buhl, Idaho). A low passage isolate $(2 \times)$, confirmed to be IHNV by serum neutralization tests, was used to produce all stock virus. Virus stocks were replicated in CHSE- 214 cells at $18^{\circ} \mathrm{C}$ and stored at $-75^{\circ} \mathrm{C}$.

Determination of IHNV susceptibility. From each family, 2 groups of 50 fish (total of 100 fish) were exposed to $10^{4}$ plaque forming units (PFU) $\mathrm{ml}^{-1}$ in a volume of water that was $10 \times$ the weight of the fish as previously described (Engelking \& Leong 1989). Challenges were conducted in closed systems for $1 \mathrm{~h}$ with aeration. Each group was then placed in separate 221 aquaria receiving constant temperature $\left(15^{\circ} \mathrm{C}\right)$, ultraviolet disinfected, single pass water. Fish were monitored for mortality and fed ad libitum $(4 \times)$ daily. Each experiment was terminated after $21 \mathrm{~d}$. A minimum of $20 \%$ of each day's mortality from each aquaria were examined for bacteria and virus, as previously described (Thoesen 1994). Virus titers used to infect fish or isolated from dead fish was determined by plaque assay procedures as previously described by LaPatra et al. (1991). Virus concentrations in whole fish or kidneyspleen-liver homogenates were determined for some of the dead fish examined in each test.

Induction of Mx mRNA and preparation of tissues. From the unchallenged rainbow trout in each of the 8 groups, 25 fish were injected with $10^{4} \mathrm{PFU} \mathrm{ml^{-1 }}$ of IHNV and held at $15^{\circ} \mathrm{C}$. At $48 \mathrm{~h}$ post injection, trout 
were euthanized and livers removed for northern blot analysis. The trout livers were placed immediately in $1 \mathrm{ml}$ Eppendorf tubes and snap frozen in liquid nitrogen. The caudal portion of each trout was also snap frozen for DNA extraction and subsequent RFLP analysis. All tissues were stored at $-75^{\circ} \mathrm{C}$ until analyzed. The tissues were marked with a coding scheme to ensure that the northern and Southern blot analyses were conducted as blind studies.

RNA sample preparation. Livers were placed into $2 \mathrm{ml}$ of STAT-60 RNA extraction reagent (Cinna-Biotech, Friendswood, TX, USA) in $14 \mathrm{ml}$ polypropylene tubes and homogenized using a Brinkmann polytron PT3000 for 5 s. Following homogenization, samples were allowed to stand $5 \mathrm{~min}$ at room temperature, and $0.4 \mathrm{ml}$ of chloroform was added. The mixture was then shaken for $15 \mathrm{~s}$ and allowed to stand on ice for $5 \mathrm{~min}$. Samples were then centrifuged at $8000 \mathrm{rpm}(4989 \times \mathrm{g})$ for 10 min in a Sorvall SS34 rotor. The upper aqueous layer containing the RNA was removed to another tube and precipitated by adding 0.7 volumes of isopropanol. RNA was precipitated at $4^{\circ} \mathrm{C}$ for $30 \mathrm{~min}$ and the precipitate was collected by centrifugation as described above. The supernatant was removed and the RNA pellet washed 2 times in $75 \%$ ethanol and allowed to dry at room temperature. RNA pellets were resuspended in $50 \mu \mathrm{l}$ of TE buffer and the concentration of RNA was determined by absorbance at $260 \mathrm{~nm}$. An aliquot of $10 \mu \mathrm{g}$ of total RNA was electrophoresed in agarose formaldehyde gels. Following electrophoresis, agarose gels were visualized and photographed under UV illumination and then the RNA was transferred to Nytran membranes (Schleicher and Schuell, Keene, $\mathrm{NH}$ ). Northern blots were performed as described by Maniatis et al. (1989).

DNA sample preparation. DNA was extracted from the caudal portion of each fish used for northern blot analysis of $\mathrm{Mx}$ mRNA. The caudal region of each fish was put in a stomacher bag containing $5 \mathrm{ml}$ of DNA digestion buffer $(100 \mathrm{mM} \mathrm{NaCl}, 10 \mathrm{mM}$ Tris- $\mathrm{HCl} \mathrm{pH}$ $7.8,25 \mathrm{mM}$ EDTA, $0.5 \% \mathrm{SDS}$, and $0.2 \mathrm{mg} \mathrm{ml^{-1 }}$ proteinase $\mathrm{K}$ ). The tissue was homogenized in a stomacher apparatus for $2 \mathrm{~min}$ followed by transfer of $4 \mathrm{ml}$ of the suspension to a $5 \mathrm{ml}$ tube and digestion overnight at $37^{\circ} \mathrm{C}$ with gentle rotation. After digestion, the DNA was extracted with phenol chloroform followed by ethanol precipitation. The quantity of DNA was determined by fluorometry and $15 \mu \mathrm{g}$ of DNA was cut with the HpaI restriction enzyme. Following digestion the DNA was precipitated and Southern blots were carried out as described by Maniatis et al. (1989) and Southern (1975) using Nytran membranes.

Preparation of $\mathbf{M x}$ probe. The rainbow trout RBTMx2 (Trobridge \& Leong 1997 a) cDNA clone was used to generate digoxigenin-labeled probes following the method of Lanzillo (1991). Briefly 2 primers, ME 151 (5' ATTATGAGGAGAAGGTGCGT 3'), and ME 204 (5' CGATCTTAGTCTTTGCTGTTTTC 3') were used initially to PCR amplify a fragment from $0.1 \mathrm{pg}$ of the RBTMx2 clone plasmid DNA. The reaction was performed for 1 step at $1.5 \mathrm{~min}$ at $95^{\circ} \mathrm{C}$, followed by 30 cycles of $95^{\circ} \mathrm{C}$ for $1.5 \mathrm{~min}, 55^{\circ} \mathrm{C}$ for $2 \mathrm{~min}$, and $72^{\circ} \mathrm{C}$ for $1 \mathrm{~min}$, and a final step of $72^{\circ} \mathrm{C}$ for $2 \mathrm{~min}$. The cycles were performed with final concentrations of $0.5 \mathrm{mM}$ each primer, $200 \mathrm{mM}$ each dNTP and $2.5 \mathrm{U}$ Taq polymerase in standard PCR buffer (Promega, Madison, WI). The initial PCR product was diluted in TE to $20 \mathrm{pg}$ and used as the template to generate an internal PCR fragment in which digoxigenin DNA labeling mix (Boehringer Mannheim, Mannheim, Germany) were substituted for dNTPs. The reaction was performed with the primers ME 140 (5' AGAAGGACCTTGCGCTGC 3') and ME 201 (5' CAAGTTGATTGTTTCTTGCTTTG $3^{\prime}$ ) for 1 step of $95^{\circ} \mathrm{C}$ for $1.5 \mathrm{~min}$, and then 35 cycles of $95^{\circ} \mathrm{C}$ for $1.5 \mathrm{~min}, 56^{\circ} \mathrm{C}$ for $2 \mathrm{~min}$, and $72^{\circ} \mathrm{C}$ for $2 \mathrm{~min}$, and a final cycle of $72^{\circ} \mathrm{C}$ for $5 \mathrm{~min}$. The amplification was performed with final concentrations of $0.5 \mathrm{mM}$ each primer, $2.5 \mathrm{U}$ Taq polymerase in standard PCR buffer (Promega). The final concentrations of dNTPs were: $100 \mathrm{mM}$ each of dATP, dCTP, and dGTP, $65 \mathrm{mM}$ dTTP, and $35 \mathrm{mM}$ DIG-11-dUTP. This resulted in a digoxigenin labeled $448 \mathrm{nt}$ fragment of the RBTMx2 gene corresponding to nt 139 to nt 587 of the RBTMx2 cDNA (Genbank Acc. U47945). This is a conserved 5 region of the $\mathrm{Mx}$ gene that is found in all $3 \mathrm{Mx}$ cDNA clones.

Northern and Southern blot detection. For all blots, the hybridization and chemiluminescent detection were performed using the methods of Holtke et al. (1992) with some madification in the hybridization and washing temperatures. Hybridization was carried out at $42^{\circ} \mathrm{C}$. The hybridization solution was $50 \%$ formamide with $5 \times \mathrm{SSC}(1 \times \mathrm{SSC}$ is $0.15 \mathrm{M} \mathrm{NaCl}, 0.015 \mathrm{M} \mathrm{Na}$ citrate), $2 \%$ wt/vol blocking solution (Boehringer), $0.1 \%$ (wt/vol) N-lauryl sarkosine and $0.02 \%$ (wt/vol) SDS. Membranes were washed twice for $15 \mathrm{~min}$ at room temperature with $2 \times \mathrm{SSC}, 0.1 \% \mathrm{SDS}$, followed by 2 washes of 15 min each at $55^{\circ} \mathrm{C}$ with $0.1 \times \mathrm{SSC}$, $0.15 \%$ SDS.

\section{RESULTS}

\section{Challenge data from IHNV susceptibility crosses}

The level of resistance to IHNV infection in the progeny of selected rainbow trout crosses was assessed using standard challenge procedures. The low susceptibility crosses resulted in significantly lower cumulative percent mortalities than the 4 groups of high sus- 
Table 1. Comparison of rainbow trout groups selected for low and high susceptibility to IHNV. Cumulative percent mortality (CPM), mean number of days to death (MDD) and restriction fragment length polymorphism determined heterozygosity (RFLP Het) measurements were made for $66 \mathrm{~d}$ old rainbow trout Oncorhynchus mykiss selected for low and high susceptibility crosses after waterborne exposure to IHNV

\begin{tabular}{|c|c|c|c|c|c|c|c|c|c|}
\hline \multirow[b]{2}{*}{ Group } & \multicolumn{3}{|c|}{ Low susceptibility crosses } & \multirow[b]{2}{*}{ RFLP Het ${ }^{b}$} & \multicolumn{5}{|c|}{ High susceptibility crosses } \\
\hline & Size $^{d}(g)$ & CPM & MDD & & Group & $\operatorname{Size}^{\mathrm{H}}(\mathrm{g})$ & CPM & MDD & RFLP Het ${ }^{b}$ \\
\hline A & 0.9 & $\begin{array}{c}23 \% \\
(23 / 99)\end{array}$ & 13.1 & $\begin{array}{c}2 / 24 \\
\text { a15:b9 }\end{array}$ & C & 1.0 & $\begin{array}{c}72 \% \\
(72 / 100)\end{array}$ & 11.6 & $\begin{array}{c}3 / 10 \\
\mathrm{~b} 4: \mathrm{c} 5: \mathrm{d} 1\end{array}$ \\
\hline B & 1.1 & $\begin{array}{c}34 \% \\
(34 / 100)\end{array}$ & 12.1 & $\begin{array}{c}3 / 22 \\
\mathrm{a} 4: \mathrm{c} 15: \mathrm{d} 3\end{array}$ & E & 1.1 & $\begin{array}{c}89 \% \\
(91 / 102)\end{array}$ & 9.3 & $\begin{array}{l}1 / 17 \\
c 17\end{array}$ \\
\hline $\mathrm{D}$ & 1.2 & $\begin{array}{c}40 \% \\
(42 / 105)\end{array}$ & 10.3 & $\begin{array}{c}2 / 3 \\
b 1: c 2\end{array}$ & G & 0.9 & $\begin{array}{c}55 \% \\
(59 / 108)\end{array}$ & 10.2 & $\begin{array}{c}3 / 15 \\
\text { b1:c10:e4 }\end{array}$ \\
\hline $\mathrm{F}$ & 0.8 & $\begin{array}{c}43 \% \\
(43 / 101)\end{array}$ & 10.8 & $\begin{array}{c}2 / 19 \\
\text { d13:g6 }\end{array}$ & $\mathrm{H}$ & 0.9 & $\begin{array}{c}67 \% \\
(66 / 99)\end{array}$ & 11.6 & $\begin{array}{c}3 / 7 \\
\mathrm{~d} 3: \mathrm{f} 3: \mathrm{gl}\end{array}$ \\
\hline
\end{tabular}

ceptibility crosses as determined by Student's $t$-test $(\mathrm{p}=0.03)$. The mean days to death and average size of the fish were not significantly different between the 2 groups, $p=0.34$ and $p=0.80$ respectively (Table 1 ).

\section{Northern blot analysis}

From the unchallenged rainbow trout in each of the 8 groups, 25 fish were injected with the 220-90 isolate of IHNV and analyzed for Mx mRNA expression $48 \mathrm{~h}$ post-injection. Trout were challenged by injection in order to maintain a uniform time of induction for $\mathrm{Mx}$ expression. Ethidium bromide staining of the electrophoresed total liver RNA showed that almost all samples (183/186) contained high quality RNA, suitable for northern blot analysis. Northern blot analysis showed that in all cases no truncated mRNA species were detected, as would be evidenced by increased electrophoretic mobility. Approximately 99\% (181/183) of the fish with high quality RNA were able to express $\mathrm{Mx}$ mRNA of the correct size. The intensity of the $\mathrm{Mx}$ northern blot $\mathrm{Mx}$ bands varied, but this may be accounted for by the differences in IHNV induction of the Mx mRNA, the differences in RNA extraction efficiency and purity of each RNA sample (Fig. 1). The uniformity of $\mathrm{Mx}$ induction was particularly striking in that injection of this virulent strain of IHNV was able to induce Mx mRNA in $99 \%$ of the analyzed fish at 48 h. As such, the northern blot analysis did not identify any groups of fish that had a predominant $\mathrm{Mx}$ - phenotype as evidenced by an inability to express Mx mRNA of the correct size.

Also of interest was the finding that some extractions did not contain appreciable amounts of ribosomal RNA.
However, some of these lanes contained other bands (e.g. Fig. 1, lane 2). It was not determined what these bands were, but we speculate that these other bands may be IHNV viral RNA representing an extreme in-

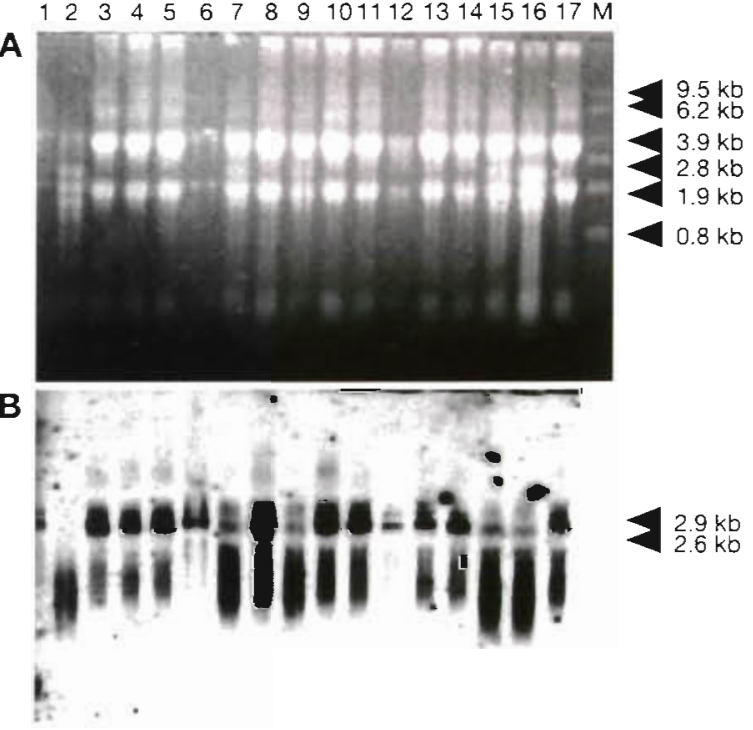

Fig. 1. Expression of Mx mRNA in rainbow trout Group B after injection with IHNV. Rainbow trout were injected intraperitoneally with the 220-90 strain of IHNV, and $48 \mathrm{~h}$ post-injection trout were euthanized; the liver tissue was excised and frozen in liquid nitrogen. RNA was extracted and $10 \mu \mathrm{g}$ of total RNA was analyzed by northern blot using the $448 \mathrm{nt}$ digoxigenin-labeled gene probe. Lanes 1 to 17 are liver total RNA from the IHNV low susceptibility Group B trout. Lane M is the RNA molecular weight standards. (A) Agarose gel under UV illumination. (B) Corresponding northern blot showing expression of the 2.9 and $2.6 \mathrm{~kb}$ transcript sizes of Mx mRNA. Lane 2 shows degradation of rRNA and other predominant RNA bands 


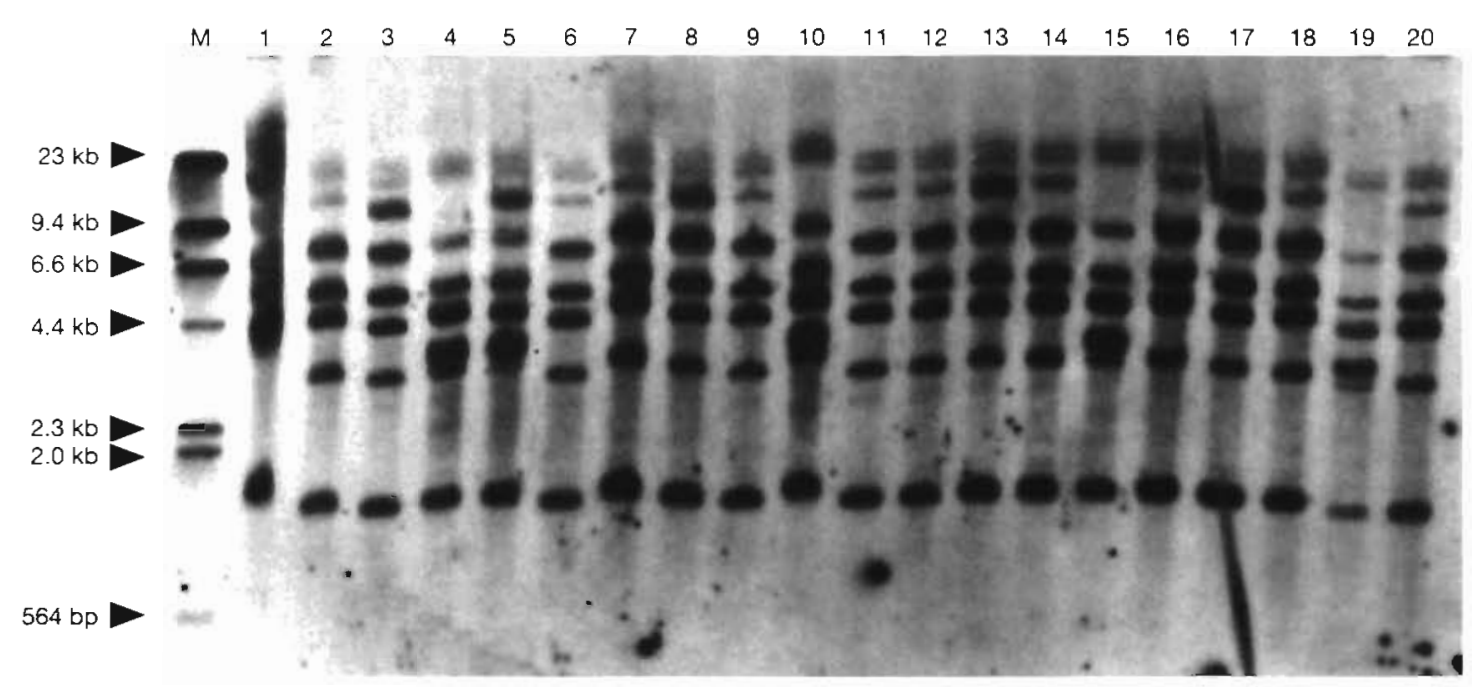

Fig. 2. Mx RFLP analysis of rainbow trout from Group B. DNA was extracted from the caudal portion of rainbow trout fry, digested with the Hpal restriction enzyme, and analyzed by Southern blotting. Specific hybridization of Mx sequences was detected with a 448 nt digoxigenin-labeled $\mathrm{Mx}$ gene probe. Lane $\mathrm{M}$ is the HindIII digested, digoxigenin-labeled lambda DNA molecular weight markers. Lanes 1 to 17 are trout from the IHNV low susceptibility Group B. The polymorphism patterns a, c, and $d$ were represented in this group as follows: RFLP pattern a-lanes 4, 10, 15, and 19; RFLP pattern c-lanes 2, 3, 6, 7, 8, 9, 11, 12, 13, 14, $16,17,18$, and 20 ; pattern $\mathrm{d}$-lanes 1 and 5

fection of the liver in these samples. Generally fish infected with IHNV at $66 \mathrm{~d}$ post-hatching do not show signs of the disease until 3 to $4 \mathrm{~d}$ after infection. How ever, the virus mRNA and proteins are being synthesized at a very high rate at this time.

\section{Southern blot analysis}

Although the northern blot analysis did not show any groups of fish with an $\mathrm{Mx}$ - phenotype, Southern blot analysis was performed to examine the RFLP patterns (Fig. 2). RFLP patterns were scored to give 7 unique patterns (a to g) (Fig. 3) among the 8 groups of rainbow trout crosses (A to $\mathrm{H}$ ). For some groups the quality of the DNA extracted was poor and limited the number of samples available for RFLP analysis. It was interesting to note that a comparison of the RFLP patterns in terms of the heterozygosity of the Mx locus for each group varied. Further, the group with the highest mortality had the least heterozygosity at the Mx locus with only 1 RFLP pattern per 17 fish examined (Table 1).

\section{DISCUSSION}

The $\mathrm{Mx}$ proteins of mammals are specifically and transiently induced by IFN to high levels of expression. Some members of this protein family are efficient inhibitors of viral replication of negative stranded RNA viruses. Extensive studies have shown clearly that the murine Mx1 protein confers resistance to influenza virus challenge and $\mathrm{Mx}$ - mice with deletions in the Mx1 gene are very susceptible to lethal influenza infection. These $\mathrm{Mx}$ - alleles occur rather frequently in both wild and laboratory mice strains and the absence of the appropriate Mx mRNA can be used as an indicator of sensitivity to influenza virus infection. We chose

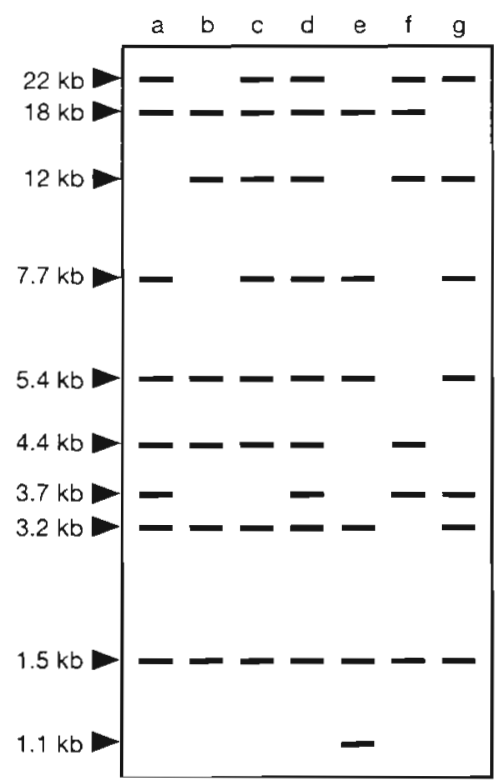

Fig. 3. Representative Mx RFLP patterns. Seven RFLP patterns designated a to $g$ were seen in the 8 groups of trout crosses $\mathrm{A}$ to $\mathrm{H}$. Band sizes for each RFLP pattern are shown 
to examine trout $\mathrm{Mx}$ expression at a commercial trout farm to determine whether a difference in Mx expression would correlate with susceptibility to IHNV infection in rainbow trout. The expression of Mx mRNA and the corresponding RFLP patterns at the Mx locus were examined in trout crosses known to have differences in susceptibility to IHNV.

Approximately $99 \%$ of 183 rainbow trout examined were able to express Mx mRNA of the correct size at $48 \mathrm{~h}$ post injection with a virulent isolate of IHNV. The ability to express Mx mRNA of the correct size demonstrated that if there was a defect in $\mathrm{Mx}$ expression for some rainbow trout, it was not due to a deletion resulting in a truncated mRNA. It should be noted that a point mutation, resulting in a truncated $\mathrm{Mx}$ protein would not be detected by this assay.

In a previous report, a single exon probe was used to map the Mx RFLP patterns in the trout genome after digestion with BamHI, and EcoR1 (Trobridge \& Leong 1995). We subsequently found that by using the restriction enzyme HpaI, polymorphism differences between individuals of different trout stocks were more easily detected. The $448 \mathrm{nt}$ probe used in the study reported here spans the region from putative exons 3 to 6 of the rainbow trout $\mathrm{Mx}$ gene and yielded a higher number of bands than the single exon probe (data not shown). The murine Mus musculus and perch Perca fluviatis $\mathrm{Mx}$ genes have conserved exon-intron boundaries between $\mathrm{Mx}$ exons 3 to 8 (Staeheli et al. 1989) so it was likely that the trout would also have these conserved junctions. As such, the HpaI-based Mx RFLP assay reported here relies on the differences in Hpal sites within the introns of the $\mathrm{Mx}$ locus to differentiate $\mathrm{Mx}$ loci. The HpaI enzyme, more than likely, produces a higher degree of resolution because of the HpaI repeats in the introns found in the rainbow trout genome (Murata et al. 1993).

Because no gross defects in the ability of certain trout crosses to express Mx mRNA were observed it was not possible to identify any RFLP marker for a defect in Mx expression. However, RFLP analysis of rainbow trout using the $\mathrm{Mx}$ probe allowed us to examine the relative heterogeneity of the trout crosses at the Mx locus. The heterogeneity, as determined by the number of RFLP patterns per fish in each cross, varied from 1 RFLP pattern per 17 samples to 3 per 7 samples. Interestingly, the high IHNV susceptibility cross, Group E, had the highest cumulative mortality (89\%) and the lowest heterozygosity (1 RFLP pattern per 17 fish) at the Mx locus. A correlation between disease resistance and heterozygosity at a single loci has been demonstrated in humans and pigeons (Allison 1955, Frelinger 1972). Disease resistance and enzyme heterozygosity at 9 polymorphic loci has also been shown for rainbow trout Oncorhynchus mykiss chal- lenged with bacterial gill disease (Ferguson \& Drahushchak 1990). The potential for the Mx gene probe to differcntiate heterozygosity relevant to IHNV resistance warrants further study. It is possible that heterozygosity at the $\mathrm{Mx}$ locus is important for IHNV resistance, and the Mx gene probe may be an important disease resistance marker in terms of maintaining heterozygosity in cultured trout populations. It should be possible to develop PCR primers to the trout $\mathrm{Mx}$ exons. This would allow development of a PCR HpaI I fragment based polymorphism analysis with reduced labor requirements. Such an assay may be useful in a selective breeding program designed to enhance resistance to IHNV.

We have shown here that the differences in IHNV susceptibility of selected rainbow trout crosses within a trout farm are not correlated with the ability to express full length $\mathrm{Mx}$ mRNA. In addition, we have developed an assay to determine heterozygosity at the Mx locus that can differentiate individuals within cultured trout populations.

Acknowledgements. This research was supported by the United States Department of Agriculture to the Western Regional Aquaculture Consortium under grant 92-385007195, project no. 92080441; an Oregon Sea Grant with funds from the National Oceanic and Atmospheric Administration, Office of Sea Grant, Department of Commerce, under grant NA89AA-D-SG108, project R/FSD-16; grant NA36RG451, projects R/FSD-23 and Amend. No. 2; and a grant from the National Oceanic and Atmospheric Administration (Saltonstall-Kennedy funds), NA46FD0490. This is an Oregon Agricultural Experiment Station Technical Paper No. 11214

\section{LITERATURE CITED}

Allison AC (1955) Aspects of polymorphism in man. Cold Spring Harbor Symp Quant Biol 20:239-255

Beasley AR, Sigel MM (1967) Interferon production in coldblooded vertebrates. In Vitro 3:154-165

de Kinkelin P, Dorson M (1973) Interferon production in rainbow trout (Salmo gairdnen) experimentally infected with Egtved virus. J Gen Virol 19:125-127

de Sena J, Rio GJ (1975) Partial purification and characterization of RTG-2 fish cell interferon. Infect Immun 11: $815-822$

Eaton WD (1990) Anti-viral activity in four species of salmonids following exposure to poly-inosinic:cytidylic acid. Dis Aquat Org 9:193-198

Engelking HM, Leong JC (1989) Glycoprotein from infectious hematopoietic necrosis virus (IHNV) induces protective immunity against five IHNV types. J Aquat Anim Health 1(4):291-300

Ferguson MM, Drahushchak LR (1990) Disease resistance and enzyme heterozygosity in rainbow trout. Heredity 64 : 413-417

Fijan N, Sulimanovic D, Beazotti M, Muzinic D, Zwillenberg LO, Chilmonczyk S, Vautherot JF, de Kinkelin P (1983) Some properties of the EPC cell line from carp (Cyprinus carpio). Ann Virol (Paris) 134:207-220 
Frelinger JA (1972) The maintenance of transferrin polymorphism in pigeons. Proc Natl Acad Sci USA 69:326-329

Frese M, Kochs G, Meier-Dieter U, Siebler J, Haller O (1995) Human MxA protein inhibits tick-borne Thogoto virus but not Dhori virus. J Virol 69:3904-3909

Frese M, Kochs G, Feldmann H, Hertkorn C, Haller O (1996) Inhibition of bunyaviruses, phleboviruses, and hantaviruses by human MxA protein. J Virol 70:915-923

Gravell M, Malsberger RG (1965) A permanent cell line from fathead minnow (Pimephales promelas). Ann NY Acad Sci 126:555-565

Haller O, Acklin M, Staeheli P (1987) Influenza virus resistance of wild mice: wild-type and mutant $\mathrm{Mx}$ alleles occur at comparable frequencies. J Interferon Res 7(5):647-656

Holtke HJ, Sagner G, Kessler C, Schmitz G (1992) Sensitive chemiluminescent detection of digoxigenin-labeled nucleic acids: a fast and simple protocol and its applications. Biotechniques 12:104-113

Horisberger MA, Staeheli P, Haller O (1983) Interferon induces a unique protein in mouse cells bearing a gene for resistance to influenza virus. Proc Natl Acad Sci USA 80: $1910-1914$

Lannan CN, Winton JR, Fryer JL (1984) Fish cell lines: establishment and characterization of nine cell lines from salmonids. In Vitro 20:671-676

Lanzillo JJ (1991) Chemiluminescent nucleic acid detection with digoxigenin-labeled probes: a model system with probes for angiotensin converting enzyme which detect less than one attomole of target DNA. Anal Biochem 194: 45-53

LaPatra SE, Lauda KA, Morton AW (1991) Antigenic and virulence comparison of eight isolates of infectious hematopoietic necrosis virus from the Hagerman Valley, Idaho, USA. In: Fryer JL (ed) Proceedings of the Second International Symposium on Viruses of Lower Vertebrates. Oregon State University Press, Corvallis, p 125-129

Lindenmann J (1964) Inheritance of resistance to influenza virus in mice. Proc Soc Exp Med 116:505-509

MacDonald RD, Kennedy JC (1979) Infectious pancreatic necrosis virus persistently infects chinook salmon embryo cells independent of interferon. Virology 95:260-264

Maniatis T, Fritsch E, Sambrook S (1989) Molecular cloning: a laboratory manual Cold Spring Harbor Laboratory Press, Cold Spring Harbor, NY

McIntyre JD, Amend DF (1978) Heritability of tolerance for infectious hematopoietic necrosis virus in sockeye salmon (Oncorhynchus nerka). Trans Am Fish Soc 197:305-308

Meier E, Kunz G, Haller O, Arnheiter H (1990) Activity of rat Mx proteins against a rhabdovirus. J Virol 64:6263-6269

Murata S, Takâsaki N, Saitoh M, Okada N (1993) Determination of the phylogenetic relationships among Pacific salmonids by using short interspersed elements (SINES) as temporal landmarks of evolution. Proc Natl Acad Sci USA 90:6995-6999

Oie HK, Loh PC (1971) Reovirus Type 2: induction of viral resistance and interferon production in fathead minnow cells. Proc Soc Exp Biol Med 136:369-373

Samuel CE (1991) Antiviral actions of interferon. Interferonregulated cellular proteins and their surprisingly selective

Editorial responsibility: Larry Vaughan,

Portsmouth, New Hampshire, USA antiviral activities. Virology 183:1-11

Sano T, Nagakura Y (1982) Studies on viral diseases of Japanese fishes-VIII. Interferon induced by RTG-2 cell infected with IHN virus. Fish Pathol 17:179-185

Schneider-Schaulies S, Schneider-Schaulies J, Schuster A, Bayer M, Pavlovic J, ter Meulen V (1994) Cell typespecific MxA-mediated inhibition of measles virus transcription in human brain cells. J Virol 68(11):6910-6917

Schwemmle M, Weining KC, Richter MF, Schumacher B, Staeheli P (1995) Vesicular stomatitis virus transcription inhibited by purified MxA protein. Virology 206:545-554

Southern EM (1975) Detection of specific sequences among DNA fragments separated by gel electrophoresis. J Mol Biol 98:503-517

Staeheli P, Pavlovic J (1991) Inhibition of vesicular stomatitis virus mRNA synthesis by human MxA protein. J Virol 65: 4498-4501

Staeheli P, Haller O, Boll W, Lindenmann J, Weissmann C (1986) Mx protein: constitutive expression in 3T3 cells transformed with cloned $\mathrm{Mx}$ cDNA confers selective resistance to influenza virus. Cell 44:147-158

Staeheli P, Grob R, Meier E, Sutcliffe JG, Haller O (1988) Influenza virus-susceptible mice carry $\mathrm{Mx}$ genes with a large deletion or a nonsense mutation. Mol Cell Biol 8: $4518-4523$

Staeheli P, Yu YX, Grob R, Haller O (1989) A doublestranded RNA-inducible fish gene homologous to the murine influenza virus resistance gene $\mathrm{Mx}$. Mol Cell Biol 9: 3117-3121

Tengelsen LA, Anderson E, Leong $J$ (1989) Variation in fish interferon-like activity: cell line production and IHN virus isolate sensitivity. Fish Health Sec/Am Fish Soc Newsl $17: 4$

Thimme R, Frese M, Kochs G, Haller O (1995) Mx1 but not MxA confers resistance against tick-borne Dhori virus in mice. Virology 211:296-301

Thoesen JC (ed) (1994) Suggested procedures for the detection and identification of certain finfish and shellfish pathogens, 4th edn. Ver 1. Fish Health Section, American Fisheries Society. SOS Publications, Fairhaven, CN

Trobridge GD, Leong JC (1995) Characterization of a rainbow trout Mx gene. J Interferon Cytokine Res 15:691-702

Trobridge GD, Chiou PP, Leong JC (1997a) Cloning of the rainbow trout (Oncorhynchus mykiss) $\mathrm{Mx} 2$ and $\mathrm{Mx} 3$ CDNAs and characterization of trout Mx protein expression in salmon cells. J Virol 71:5304-5311

Trobridge GD, Chiou PP, Kim CH, Leong JC (1997b) Introduction of the $\mathrm{Mx}$ protein of rainbow trout Oncorhynchus mykiss in vitro and in vivo with poly I:C dsRNA and infectious hematopoietic necrosis virus. Dis Aquat Org 30(2): 91-98

Winter GW, Schreck CB, McIntyre JD (1980) Resistance of different stocks of transferrin genotypes of coho salmon, Oncorhynchus kisutch, and steelhead trout, Salmo gairdneri, to bacterial kidney disease and vibriosis. Fish Bull US 77:795-802

Zurcher T, Pavlovic J, Staeheli P (1992) Mouse Mx2 protein inhibits vesicular stomatitis virus but not influenza virus. Virology 187:796-800

Submitted: August 20, 1997; Accepted: November 21, 1999 Proofs received from author(s): February 2, 2000 